\title{
Diesel exhaust enhances airway responsiveness in asthmatic subjects
}

\author{
C. Nordenhäll*, J. Pourazar*, M-C. Ledin*, J-O. Levin\#, T. Sandström*, E. Ädelroth*
}

Diesel exhaust enhances airway responsiveness in asthmatic subjects. C. Nordenhäll, J.
Pourazar, M-C. Ledin, J-O. Levin, T. Sandström, E. Ädelroth. C ERS Journals Ltd 2001.

ABSTRACT: Particulate matter (PM) pollution has been associated with negative health effects, including exacerbations of asthma following exposure to PM peaks. The aim of the present study was to investigate the effects of short-term exposure to diesel exhaust (DE) in asthmatics, by specifically addressing the effects on airway hyperresponsiveness, lung function and airway inflammation.

Fourteen nonsmoking, atopic asthmatics with stable disease, on continuous treatment with inhaled corticosteroids, were included. All were hyperresponsive to methacholine. Each subject was exposed to DE (particles with a 50\% cut-off aerodynamic diameter of $10 \mu \mathrm{m}(\mathrm{PM} 10) 300 \mu \mathrm{g} \cdot \mathrm{m}^{-3}$ ) and air during $1 \mathrm{~h}$ on two separate occasions. Lung function was measured before and immediately after the exposures. Sputum induction was performed $6 \mathrm{~h}$, and methacholine inhalation test $24 \mathrm{~h}$, after each exposure.

Exposure to DE was associated with a significant increase in the degree of hyperresponsiveness, as compared to after air, of 0.97 doubling concentrations at $24 \mathrm{~h}$ after exposure $(p<0.001)$. DE also induced a significant increase in airway resistance $(p=0.004)$ and in sputum levels of interleukin (IL)-6 $(p=0.048)$. No changes were detected in sputum levels of methyl-histamine, eosinophil cationic protein, myeloperoxidase and IL-8.

This study indicated that short-term exposure to diesel exhaust, equal to high ambient levels of particulate matter, is associated with adverse effects in asthmatic airways, even in the presence of inhaled corticosteroid therapy. The increase in airway responsiveness may provide an important link to epidemiological findings of exacerbations of asthma following exposure to particulate matter.

Eur Respir J 2001; 17: 909-915.
*Dept of Respiratory Medicine and Allergy, University Hospital, Umeå, Sweden and ${ }^{\#}$ Institute for Working Life, Dept of Occupational Chemistry, Umeå, Sweden.

Correspondence: E. Ädelroth, Dept of Respiratory Medicine and Allergy, University Hospital, S-90185 Umeå, Sweden.

Fax: 4690141369

\section{Keywords: Asthma}

airway responsiveness

diesel exhaust

induced sputum

Received: September 72000

Accepted after revision January 18 2001

This work was supported by the Swedish Heart and Lung Foundation.
During the last decade, several epidemiological studies have provided convincing evidence for an association between ambient levels of particulate matter and various health outcome indices, including respiratory symptoms [1], impaired lung function [2], exacerbations of asthma [3, 4], emergency room visits $[1,5]$, and an increased risk of respiratory illness in children [6]. Importantly, several studies have suggested that individuals with pre-existing respiratory disease such as asthma are more sensitive to elevated ground levels of particulate matter (PM) pollution as compared to healthy subjects $[7,8]$. Although the epidemiological data linking PM to various health effects is strong and consistent, the knowledge about underlying biological mechanisms, as well as the causality of the observed associations, is still limited.

Diesel exhaust (DE) is a major source of particulate matter [9]. Studies conducted in London have shown that the contribution from DE particles to the concentration of particles with a $50 \%$ cut-off aerodynamic diameter of $10 \mu \mathrm{m}$ value (PM10) can account for as much as $87 \%$ of the particulate emission from vehicles [10]. The particles consist of a carbonaceous core to which various components including acids, aldehydes, hydrocarbons and transition metals can be absorbed.
DE particles have further been shown to absorb antigens on to their surface, and thereby potentially increase the deposition of allergens in the respiratory tract [11].

Previously, knowledge about the biological effects of DE was predominantly based on animal studies. However, in recent years, a series of experimental studies has been conducted to evaluate the effects of DE in humans. Using the same exposure system as in the present study, short-term exposure to DE has been shown to induce an acute inflammatory response in human airways, with cellular and cytokine changes detected in sputum, bronchoalveolar lavage and bronchial biopsies [2, 12-15]. In addition, nasal instillation of DE particles has been shown to increase immunoglobulin-E in nasal lavage from atopic subjects, and further, to skew cytokine production towards a Th2 type phenotype when instillation of DE particles were combined with allergen challenge [16]. Altogether, experimental data have suggested a proinflammatory and allergy-enhancing effect of DE.

In spite of the epidemiological data identifying asthmatics as a sensitive group to PM, the number of controlled exposure studies investigating this issue is still limited. This study hypothesized that the mechanisms by which PM increases respiratory morbidity 
may involve several components of the asthmatic disease. The aim of the present study was, therefore, to elucidate the effects of short-term exposure to DE in asthmatic airways by specifically addressing the effects on: 1) airway hyperresponsiveness; 2) lung function; and; 3) airway inflammation.

\section{Methods}

\section{Subjects}

The study population comprised 14 never-smoking subjects (seven females and seven males, mean age 26 yrs, range 22-57 yrs) with diagnosed asthma according to the American Thoracic Society guidelines. Inclusion characteristics of all subjects are presented in table 1 . All subjects were atopic with a positive skinprick test to at least one airborne allergen (Soluprick SQR, ALK, Denmark). The asthmatics were hyperresponsive to methacholine (provocative concentration causing a $20 \%$ fall in forced expiratory volume in one second (FEV1) (PC20) methacholine $<8 \mathrm{mg} \cdot \mathrm{mL}^{-1}$ ). All subjects had controlled, stable asthma and were free of respiratory tract infection for $\geqslant 6$ weeks prior to and during the study period. The subjects used inhaled short acting $\beta_{2}$-agonists as needed, as well as daily medication with inhaled corticosteroids (400-1200 $\mu \mathrm{g})$. Bronchodilators were withheld for at least $8 \mathrm{~h}$ before each procedure, whereas the daily required doses of inhaled corticosteroids were continued. As part of the screening procedure for participation in the study, all subjects were tested for their ability to produce sputum on induction with hypertonic saline. The study was conducted during the winter to avoid pollen season. Verbal and written informed consent was obtained from all individuals and the study was approved by the Local Ethics Committee.

\section{Study design}

The study was conducted in a single-blind, crossover design with each subject acting as their own control. All subjects were exposed to filtered air and diesel exhaust (PM10 $300 \mu \mathrm{g} \cdot \mathrm{m}^{-3}, 1.2$ parts per million ( $\mathrm{ppm}$ ) nitrogen dioxide) for $1 \mathrm{~h}$ on two separate occasions, at least 3 weeks apart and in a randomized sequence. During exposures, the subjects alternated between rest and moderate exercise on a cycle ergometer at $15 \mathrm{~min}$ intervals. The level of exercise giving a minute ventilation of $20 \mathrm{~L} \cdot \mathrm{min}^{-1} \cdot \mathrm{m}^{-2}$ body surface area was determined on a separate visit prior to the study and subsequently used for both exposures. Lung function was measured before and immediately after the exposures. Sputum induction with hypertonic saline was performed $6 \mathrm{~h}$ after each exposure. Methacholine inhalation test was conducted $24 \mathrm{~h}$ after each exposure to evaluate the level of airway hyperresponsiveness. Further, for clinical reasons, in order to assure that all subjects had stable asthma with no exacerbation during the study, an additional visit including clinical examination and methacholine inhalation challenge was carried out 3-7 days prior to each exposure.

\section{Exposure}

The exposure system used in this study has been carefully evaluated and validated [17]. All exposures were performed in an environmental chamber according to a previously described standard protocol $[2,12$, $13,17]$. DE was generated by an idling Volvo diesel engine (Volvo TD45, 4.5 L, 4 cylinders, model 1991, $\left.680 \mathrm{revs} \cdot \mathrm{min}^{-1}\right)$. The concentrations of particles (number $\cdot \mathrm{cm}^{-3}$ ), oxides of nitrogen $\left(\mathrm{NO}_{2}, \mathrm{NO}\right)$, carbon monoxide and hydrocarbons (HCs) were continuously recorded in the exposure chamber as previously described [13]. A Miran 1-A, an infrared-instrument (Foxboro Co., East Bridgewater, MA, USA), was used for analysis of $\mathrm{CO}$. Oxides of nitrogen were analysed with a chemiluminescence instrument, (ECO-Physics CLD 700, Boo Instruments, Stockholm, Sweden). HCs were analysed with an FID-instrument, model 3-300 (JUM Engineering GmbH, Munich, Germany). Mass of particles $\left(\mu \mathrm{g} \cdot \mathrm{m}^{-3}\right)$ was determined by weighing PM collecting filters. Approximately $90 \%$ of the exhaust was shunted away and the remaining part diluted with

Table 1.-Inclusion data of subjects

\begin{tabular}{|c|c|c|c|c|c|c|c|}
\hline Subject & $\begin{array}{l}\text { Age } \\
\text { yrs }\end{array}$ & Sex & $\begin{array}{l}\text { Height } \\
\mathrm{cm}\end{array}$ & $\begin{array}{l}\text { Weight } \\
\text { Kg }\end{array}$ & $\begin{array}{c}\text { VC } \\
\% \text { pred }\end{array}$ & $\begin{array}{l}\text { FEV1 } \\
\% \text { pred }\end{array}$ & $\begin{array}{c}\text { Inhaled } \\
\text { Corticosteroids* }\end{array}$ \\
\hline 1 & 57 & $\mathrm{~F}$ & 164 & 64 & 138 & 112 & 800 \\
\hline 2 & 23 & $\mathrm{M}$ & 178 & 76 & 94 & 85 & 1200 \\
\hline 3 & 24 & M & 178 & 73 & 96 & 97 & 400 \\
\hline 4 & 23 & $\mathrm{~F}$ & 169 & 56 & 111 & 92 & 400 \\
\hline 5 & 22 & $\mathrm{~F}$ & 163 & 68 & 116 & 112 & 400 \\
\hline 6 & 24 & $\mathrm{M}$ & 176 & 68 & 114 & 117 & 400 \\
\hline 7 & 27 & $\mathrm{~F}$ & 175 & 61 & 114 & 83 & 400 \\
\hline 8 & 23 & $\mathrm{~F}$ & 167 & 57 & 115 & 102 & 800 \\
\hline 9 & 43 & $\mathrm{M}$ & 177 & 91 & 108 & 84 & 800 \\
\hline 10 & 25 & $\mathrm{M}$ & 180 & 100 & 100 & 98 & 400 \\
\hline 11 & 39 & $\mathrm{M}$ & 184 & 82 & 111 & 85 & 800 \\
\hline 12 & 35 & $\mathrm{~F}$ & 160 & 80 & 120 & 111 & 800 \\
\hline 13 & 28 & $\mathrm{M}$ & 187 & 108 & 105 & 94 & 800 \\
\hline 14 & 34 & $\mathrm{~F}$ & 164 & 61 & 104 & 76 & 800 \\
\hline
\end{tabular}

*: Budesonide (Pulmicort $\AA$ Turbuhaler $\AA$ ) in $\mu \mathrm{g} \cdot 24 \mathrm{~h}^{-1}$; F: female; M: male. 
air and fed into the chamber at a steady state concentration. Air in the chamber was repeatedly changed every 2-3 min, with the waste air being extracted through a tube in the ceiling. The DE entering the environmental chamber was standardized to give a particle concentration of $300 \mu \mathrm{g} \cdot \mathrm{m}^{-3}$, associated with a median steady state $\mathrm{NO}_{2}$ concentration of $1.2 \mathrm{ppm}$. Mean concentrations of NO, HCs and $\mathrm{CO}$ were $3.4 \mathrm{ppm}, 2.6 \mathrm{ppm}$ and $9.1 \mathrm{ppm}$, respectively. The temperature was maintained at $20^{\circ} \mathrm{C}$.

\section{Methacholine inhalation test}

The methacholine inhalation test was performed in accordance with the method described by JUNIPER et al. [18]. The test aerosols were generated continuously by a Wright's nebulizer (Roxon Medi-Tech, Montreal, PQ, Canada), delivered into a Hans Rudolph two-way valve (type 1410B, Somedic sales AB, Farsta, Sweden) and inhaled through a mouthpiece by quiet tidal breathing for $2 \mathrm{~min}$ with the nose clipped. The nebulizer output was $0.13 \mathrm{~mL} \cdot \mathrm{min}^{-1}$. Normal saline was inhaled first, followed by doubling concentrations of methacholine $\left(0.06-16 \mathrm{mg} \cdot \mathrm{mL}^{-1}\right)$ at intervals of $5 \mathrm{~min}$. The response was measured by FEV1 before and at 30, 90 and $180 \mathrm{~s}$ after each inhalation. The inhalations were discontinued when there was a fall in FEV1 of $20 \%$ or more below the lowest post saline value. Results were expressed as PC20 obtained from the log dose-response curve by linear interpolation of the 2 last points expressed in noncumulative units. The variability of the method is \pm one doubling concentration [19].

\section{Lung function test}

Lung function responses were measured using a computerized whole body plethysmograph (system 2800, Sensor Medics Corp., CA, USA). Forced vital capacity (FVC), FEV1 and airway resistance ( $R$ aw) were measured immediately before and after each exposure.

\section{Sputum induction}

Sputum induction was performed by a method slightly modified from that described by PIN et al. [20]. Briefly, hypertonic saline $(3 \%)$ was nebulized using an ultrasonic nebulizer (DeVilbiss 2000, DeVilbiss Co, Somerset, PA, USA) with an output of $1.5 \mathrm{~mL} \cdot \mathrm{min}^{-1}$. All subjects received an inhaled $\beta_{2}$-agonist $(0.5 \mathrm{mg}$ terbutaline) before the induction. Inhalation was conducted at 3 intervals of $7 \mathrm{~min}$. FEV1 was monitored before commencing and after every inhalation period. Following each inhalation interval, subjects were advised to rinse their mouth with water and blow their nose before trying to cough sputum into a sterile plastic container. The obtained samples were kept on ice up to $1 \mathrm{~h}$ prior to processing.

\section{Sputum processing}

Sputum was processed according to the method described by Pizzichini et al. [21]. Briefly, portions appearing more viscid and dense were selected from the expectorated samples and transferred to a $10 \mathrm{~mL}$ siliconized tube. After adding $0.1 \%$ diothiotreitol (DTT) at a volume equal to four times the selected sputum weight, the sputum was rocked for $15 \mathrm{~min}$ to dissolve the mucus and disperse the cells. Phosphate buffered saline (PBS) was then added at a volume equal to that of DTT and the rocking continued for $5 \mathrm{~min}$. The mixture was filtered through a $48 \mu \mathrm{m}$ mesh nylon filter into another $10 \mathrm{~mL}$ tube and centrifuged at $300 \times g$ for $10 \mathrm{~min}$ at $4^{\circ} \mathrm{C}$. The supernatant was then separated from the cell pellet, re-centrifuged at $1,000 \times g$ for $10 \mathrm{~min}$ to further remove debris, aspirated and stored in Eppendorf tubes at $-70^{\circ} \mathrm{C}$ for later analyses. The cell pellet was resuspended in $1,000 \mu \mathrm{L}$ PBS and total cell count and cell viability were determined in a haemocytometer using trypan blue. Cell suspension was adjusted to $0.5 \times 10^{6}$ cells $\cdot \mathrm{mL}^{-1}$ and $50 \mu \mathrm{L}$ were placed in each cup of a Shandon 3 cytocentrifuge (Shandon Southern Instruments Inc., Sewikly, PA, USA). Cytospins were made on pre-wet slides, prepared at $400 \mathrm{rpm}$ for $5 \mathrm{~min}$ and stained with May-Grünwald-Giemsa. At least 400 nonsquamous cells were counted and the differential cell counts were expressed as a percentage of the total nonsquamous cell count. The proportion of squamous cells was obtained by counting 400 additional cells and expressing this as a percentage of the total number of cells. Samples were considered adequate for analysis if the squamous cell contamination was $<20 \%$ and the viability $>50 \%$. Total cell count was calculated by dividing the total number of cells by the volume of processed sputum $(1 \mathrm{mg}=1 \mu \mathrm{L})$.

\section{Fluid phase measurements}

The sputum supernatant samples were analysed for six different soluble proteins, including interleukin (IL)-6, IL-8, IL-10, methyl-histamine, eosinophil cationic protein (ECP) and myeloperoxidase (MPO). IL-6, IL-8 and IL-10 were measured with commercial enzyme linked immunosorbent assay kits (R\&D Systems Inc., Abingdon, UK). Levels of methylhistamine, ECP and MPO were determined using sensitive commercial radioimmunoassay kits (Pharmacia \& Upjohn, JAB, Uppsala, Sweden).

\section{Statistical Analysis}

Wilcoxon's nonparametric signed-ranks test for paired observations was used to compare sputum data on cells and soluble markers after air and diesel exhaust exposures. Comparison of lung function data was performed with the paired samples t-test. All methacholine values were log-transformed before statistical analysis. Results are presented as geometric mean \pm geometric standard error of the mean (SEM). The comparison between methacholine values after air and diesel exposure was done with the t-test. A $\mathrm{p}$-value $<0.05$ was considered significant. 


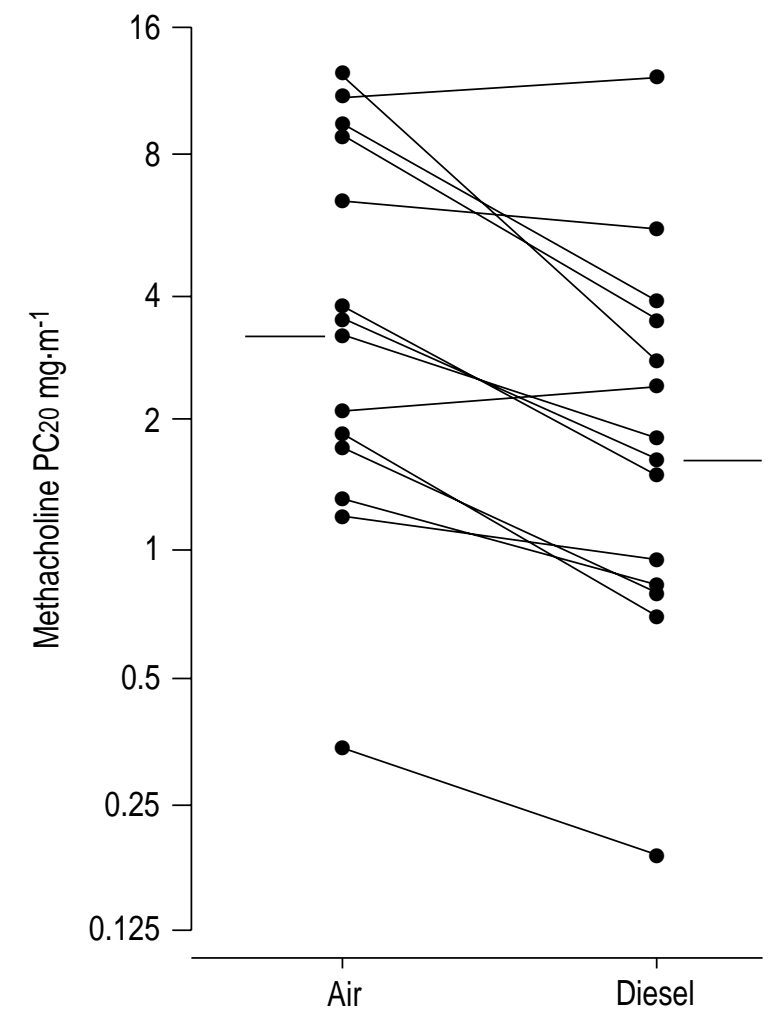

Fig. 1. - Methacholine provocative concentration causing a $20 \%$ fall in forced expiratory volume in one second (PC20) in 14 asthmatic subjects at $24 \mathrm{~h}$ following exposure to air and diesel exhaust. Bars indicate mean values. Please note the y-axis indicates doubling concentration.

\section{Results}

\section{Airway hyperresponsiveness}

The individual PC20 data following air and diesel exposures are presented in figure 1. The degree of hyperresponsiveness was significantly increased $24 \mathrm{~h}$ after exposure to DE as compared to after air, with the mean methacholine PC20 following diesel and air being $1.77 \pm 1.35 \mathrm{mg} \cdot \mathrm{mL}^{-1}$ and $3.47 \pm 1.36 \mathrm{mg} \cdot \mathrm{mL}^{-1}$, respectively $(\mathrm{p}<0.001)$. The mean diesel versus air shift in the PC20 was 0.97 doubling concentrations. In addition, the increase in airway responsiveness following diesel exhaust was confirmed by comparing the data from the methacholine tests performed 3-7 days before the exposures with the postexposure data. A significant difference was seen between the prediesel data (PC20

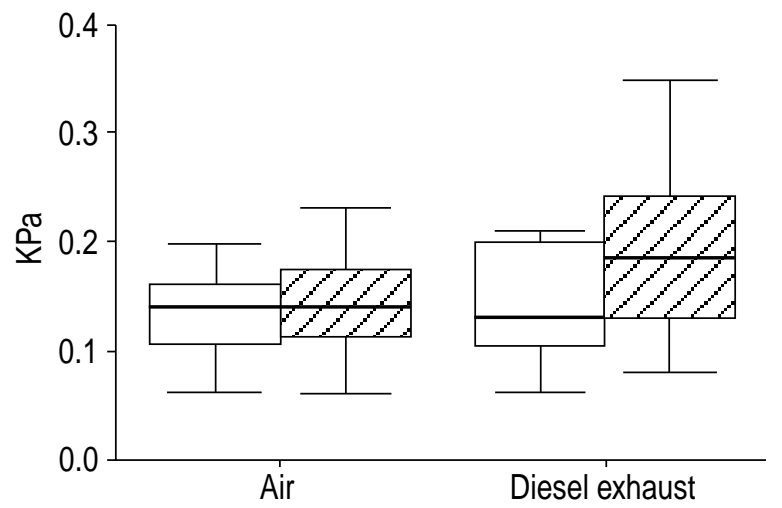

Fig. 2. - Airway resistance (Raw) before and directly after exposure in 13 subjects for air and diesel exhaust. $\square$ : before exposure; $\mathbb{Z}$ : after exposure. The thick horizontal lines represent median values, boxes represent 25 th -75 th percentile range and the extended bars represent the largest and smallest observed values within 1.5 box lengths.

$\left.2.79+1.25 \mathrm{mg} \cdot \mathrm{mL}^{-1}\right)$ and the postdiesel exposure data (PC20 1.77 $\left.\pm 1.35 \mathrm{mg} \cdot \mathrm{mL}^{-1} ; \mathrm{p}=0.005\right)$. As expected, no change was seen between the pre-air (PC20 $\left.2.53 \pm 1.25 \mathrm{mg} \cdot \mathrm{mL}^{-1}\right)$ and post-air exposures $\left(\mathrm{PC}_{20}\right.$ $3.47 \pm 1.36 \mathrm{mg} \cdot \mathrm{mL}^{-1}$ ). The change in PC20 (prediesel minus postdiesel versus pre-air minus postair) was also significant $(\mathrm{p}=0.001)$.

\section{Lung function test}

Lung function data are presented in table 2. Raw data is based on 13 subjects, since one subject was not able to complete the Raw measurement due to technical difficulties. Following exposure to DE, a significant increase in airway resistance was induced compared with after air ((Raw air minus pre-air)/pre-air versus (Raw postdiesel minus prediesel)/prediesel), $\mathrm{p}=0.004$ (fig. 2). No changes were detected in FVC or FEV1 values between exposures.

\section{Sputum cell counts and inflammatory mediators}

Adequate samples were obtained from all subjects following both exposures. The median (interquartile range) weight of the selected sputum portion was $395 \mathrm{mg}(235-592 \mathrm{mg})$. Median cell viability was $77 \%$ $(72-81 \%)$ and median salivary contamination, as indicated by the percentage of squamous cells, was

Table 2. - Changes in lung function parameters directly following exposure to air and diesel exhaust

\begin{tabular}{lcccccc}
\hline Parameter & \multicolumn{2}{c}{ Air } & & \multicolumn{2}{c}{ Diesel exhaust } & p-value* \\
\cline { 2 - 3 } \cline { 5 - 6 } & Pre-exposure & Postexposure & & Pre-exposure & Postexposure & \\
\hline FVC L & $4.73 \pm 0.23$ & $4.72 \pm 0.24$ & & $4.68 \pm 0.24$ & $4.72 \pm 0.25$ & NS \\
FEV1 L & $3.62 \pm 0.20$ & $3.68 \pm 0.21$ & & $3.58 \pm 0.21$ & $3.63 \pm 0.23$ & NS \\
Raw cm $\mathrm{Cm}_{2} \mathrm{O} \cdot \mathrm{L}^{-1} \cdot \mathrm{s}$ & $0.142 \pm 0.012$ & $0.156 \pm 0.015$ & & $0.142 \pm 0.013$ & $0.194 \pm 0.022$ & 0.004 \\
\hline
\end{tabular}

Data presented as mean \pm SEM. NS: no significant difference; FVC: forced vital capacity; FEV1: forced expiratory volume in one second; Raw: airway resistance. *: Comparison of lung function changes between air and diesel exposure ((post-air-pre-air)/ pre-air versus (postdiesel-prediesel) prediesel) using paired samples t-test. 
Table 3. - Comparison of cell counts and soluble mediators in induced sputum at $6 \mathrm{~h}$ following exposure to air and diesel exhaust

\begin{tabular}{lccc}
\hline & Air & Diesel exhaust & p-value \\
\hline Total cell counts, $\times 10^{6} \cdot \mathrm{mL}^{-1}$ & $3.60(2.37-4.28)$ & $3.52(2.09-5.19)$ & $\mathrm{NS}$ \\
Neutrophils \% & $41.3(13.0-51.2)$ & $36.3(18.8-62.6)$ & $\mathrm{NS}$ \\
Macrophages \% & $49.8(41.1-71.6)$ & $53.6(32.6-71.1)$ & $\mathrm{NS}$ \\
Lymphocytes \% & $3.0(1.8-4.2)$ & $2.4(1.7-3.0)$ & $\mathrm{NS}$ \\
Eosinophils \% & $1.3(0.6-2.0)$ & $0.8(0.2-2.6)$ & $\mathrm{NS}$ \\
Ciliated Epithelial cells, \% & $3.0(1.9-5.3)$ & $2.8(1.1-6.1)$ & $\mathrm{NS}$ \\
Methyl-histamine, $\mu \mathrm{g} \cdot \mathrm{L}^{-1}$ & $0.14(0.07-0.23)$ & $0.08(0.07-0.14)$ & $\mathrm{NS}$ \\
ECP, $\mu \mathrm{g} \cdot \mathrm{L}^{-1}$ & $31.6(9.0-63.6)$ & $22.1(9.7-51.1)$ & $\mathrm{NS}$ \\
MPO, $\mu \mathrm{g} \cdot \mathrm{L}^{-1}$ & $119.0(62.7-367.7)$ & $84.2(65.7-275.3)$ & $\mathrm{NS}$ \\
IL-8, $\mathrm{pg} \cdot \mathrm{mL}^{-1}$ & $35.0(0.0-131.2)$ & $35(0.0-108.8)$ & $\mathrm{NS}$ \\
IL-6, $\mathrm{pg} \cdot \mathrm{mL}^{-1}$ & $8.0(5.2-13.8)$ & $12.8(7.4-14.9)$ & 0.048 \\
\hline
\end{tabular}

Results are expressed as median (interquartile range). NS: nonsignificant; ECP: eosinophil cationic protein; MPO: myeloperoxidase; IL: interleukin.

$6.4 \%(2.9-11.3 \%)$. No changes in total or differential cell counts were detected following exposure to DE as compared to air (table 3). A significant increase was seen in the fluid phase concentration of IL- 6 after exposure to DE compared with after air, whereas no significant changes were detected in the levels of IL-8, ECP, MPO or methyl-histamine (table 3).

\section{Discussion}

This study tested the hypotheses that short-term exposure to DE would affect all three characteristic features of asthma: airway hyperresponsiveness, bronchoconstriction and airway inflammation. The most important finding was that short-term exposure to DE increased airway hyperresponsiveness to methacholine in asthmatic airways. Exposure to DE was also associated with an immediate increase in $R$ aw and elevated levels of IL-6 in sputum detected $6 \mathrm{~h}$ after exposure.

Airway hyperresponsiveness is an important feature of asthma and has been shown to correlate well with the severity of the disease [22]. In the present study, methacholine data obtained at $24 \mathrm{~h}$ postair exposure was compared with the postdiesel data, and it was found that exposure to DE induced an increase in airway responsiveness equal to a shift in PC20 methacholine of almost one doubling concentration. The relevance of this finding is supported by the consistency of the data, with 12 of 14 subjects showing decreased PC20 values following DE exposure, as well as by a high level of statistical significance. The increase in airway responsiveness was further confirmed by analysis of the change from pre-exposure to postexposure revealing a significant increase following exposure to DE. In concordance with the epidemiological data suggesting a 1-4 day lag effect for most health outcomes to PM [4], the increase in airway responsiveness was detected $24 \mathrm{~h}$ after exposure. This finding indicates a long lasting response to DE in asthmatic airways. Importantly, the late increase in airway responsiveness presented here is of particular interest, as a prolonged response may not only be hazardous by itself, but might also increase the time when other stimuli can trigger asthma symptoms.

DE was associated with a significant increase in IL-6, as recently shown in healthy subjects at the same timepoint after DE exposure [2]. The increase in IL-6 probably represents an acute response to DE and may result from direct effects of DE on airway epithelial cells. IL-6 is a multifunctional cytokine that exerts a number of pro-inflammatory effects, including induction of acute-phase reactions and regulation of immunological responses. Interestingly, exposure to DE particles has previously been associated with a release of IL-6 from human bronchial epithelial cells [23]. No changes were seen in ECP, MPO, methylhistamine and IL-8. However, the cytokines all showed a large variability, which makes the interpretation of data difficult.

In healthy subjects, DE has recently been shown to induce a significant increase in sputum neutrophil percentages, together with elevated levels of methylhistamine at $6 \mathrm{~h}$ following exposure [2]. In the present study, no changes were seen in these parameters, suggesting a different response in asthmatics as compared to healthy subjects. The apparent lack of a detectable cellular inflammation to DE presented here may be explained by several different factors. Firstly, all subjects were on continuous medication with inhaled corticosteroids, which may have prevented cellular influx by inhibition of neutrophil chemotactic factors and may also have suppressed mast cell degranulation, explaining the lack of a response in histamine. Secondly, the time for developing an inflammatory reaction to DE may differ between asthmatics and healthy subjects. The underlying inflammation seen in asthmatic airways may be associated with compensatory and counter-regulatory mechanisms that act to dampen or delay inflammatory changes to various stimuli. Research aimed at clarifying differences between asthmatics and healthy subjects in the response to DE is of great interest as it may provide a link to the epidemiological findings that have identified asthmatics as a sensitive subpopulation to $\mathrm{PM}$ pollution.

The biological mechanisms by which DE may induce hyperresponsiveness are still to be clarified. Recent 
animal studies have demonstrated that DE exposure, when combined with allergen challenges, enhances airway responsiveness and causes airway inflammation characterized by an increase in airway eosinophils, neutrophils, mast cells and cytokines [24-27]. Interestingly, DE alone also enhanced airway responsiveness, but did not induce any inflammatory changes [24, 26]. The increase in airway responsiveness seen in the present study was only associated with mild inflammatory changes in sputum. One obvious explanation to this mismatch is the fact that sputum inflammatory changes were investigated $6 \mathrm{~h}$ after exposure, whereas airway responsiveness was measured at $24 \mathrm{~h}$, thus reflecting different timepoints after exposure. However, it is possible that the increase in hyperresponsiveness to DE may represent a nonspecific irritative reaction, rather than a specific inflammatory response.

Furthermore, it is not known whether it is the particulate or gaseous phase of DE that is responsible for the increase in airway responsiveness presented here. Animal studies have provided evidence that the particulate fraction of DE is able to cause an increase in airway responsiveness [28], but to the best of the authors' knowledge, there are no previous experimental data concerning particulate pollution and hyperresponsiveness in humans. Regarding the gaseous phase of DE, some studies have reported an immediate increase in airway responsiveness following exposure to $\mathrm{NO}_{2}[29,30]$, whereas other studies have not [31]. Most studies have been designed to explore the immediate and early effects of $\mathrm{NO}_{2}$ and it is not clear from the literature whether $\mathrm{NO}_{2}$ is able to induce a sustained increase in airway responsiveness.

During the last decade there has been a burst of epidemiological studies investigating the health effects of particulate air pollution. Most studies have focused on addressing the effects of short-term exposure to PM and there is convincing epidemiological evidence to suggest an association between increased levels of PM and adverse health effects on both respiratory and cardiovascular morbidity and mortality [4, 32]. Most studies did not observe a particulate pollution threshold. Instead, the relative risk of morbidity and mortality has generally been shown to increase in a near-linear fashion with increased particulate concentrations [33]. In the present study, subjects were exposed to DE at a concentration of $300 \mu \mathrm{g} \cdot \mathrm{m}^{-3} \mathrm{PM} 10$, which represents a high ambient concentration encountered in busy streets of major cities, as well as in certain occupational settings. In a global perspective, more than half of the world's megacities (cities with a population $>10$ million) have annual average levels of particulate matter ranging $200-600 \mu \mathrm{g} \cdot \mathrm{m}^{-3}$ [34].

In conclusion, the findings of this study suggest that exposure to diesel exhaust is associated with adverse effects in asthmatic subjects, including an increase in airway responsiveness, airway resistance and in the release of interleukin- 6 following a short-term exposure to diesel exhaust. Importantly, these changes were observed in spite of the fact that all subjects had stable asthma and were on regular medication with inhalation steroids. The increase in airway responsiveness presented here may provide an important link to epidemiological findings of exacerbations of asthma following exposure to particulate matter peaks.

Acknowledgements. The authors acknowledge
A. Blomberg, R. Helleday and N. Stenfors for
help and advice in the preparation of this
study. The technical assistance of H. Bertilsson,
L. Skedebrant and A-B. Lundstrom is greatly
acknowledged.

\section{References}

1. Schwartz J. Air pollution and hospital admissions for respiratory disease. Epidemiology 1996; 7: 20-28.

2. Nordenhall C, Pourazar J, Blomberg A, Levin J-O, Sandstrom T, Adelroth E. Airway inflammation following exposure to diesel exhaust: A study of time kinetics using induced sputum. Eur Respir J 2000; 15: 1046-1051.

3. Lipsett M, Hurley S, Ostro B. Air pollution and emergency room visits for asthma in Santa Clara County, California. Environ Health Perspect 1997; 105: 216-222.

4. Schwartz J, Slater D, Larson TV, Pierson WE, Koenig JQ. Particulate air pollution and hospital emergency room visits for asthma in Seattle. Am Rev Respir Dis 1993; 147: 826-831.

5. Romieu I, Meneses F, Ruiz S, et al. Effects of air pollution on the respiratory health of asthmatic children living in Mexico City. Am J Respir Crit Care Med 1996; 154: 300-307.

6. Peters A, Dockery DW, Heinrich J, Wichmann HE. Short-term effects of particulate air pollution on respiratory morbidity in asthmatic children. Eur Respir J 1997; 10: 872-879.

7. Pope CA 3rd, Dockery DW. Acute health effects of PM10 pollution on symptomatic and asymptomatic children. Am Rev Respir Dis 1992; 145: 1123-1128.

8. Vedal S, Petkau J, White R, Blair J. Acute effects of ambient inhalable particles in asthmatic and nonasthmatic children. Am J Respir Crit Care Med 1998; 157: 1034-1043.

9. Quality of Urban Air Review Group 1996. Department of Environment, Third Report.

10. Source apportionment of airborne particulate matter in the United Kingdom. Airborne Particles Expert Group. 1999; pp. 157.

11. Knox RB, Suphioglu C, Taylor P, et al. Major grass pollen allergen Lol p 1 binds to diesel exhaust particles: implications for asthma and air pollution. Clin Exp Allergy 1997; 27: 246-251.

12. Salvi S, Blomberg A, Rudell B, et al. Acute inflammatory responses in the airways and peripheral blood following short term exposure to diesel exhaust in healthy human volunteers. Am J Respir Crit Care Med 1999; 159: 702-709.

13. Salvi SS, Nordenhall C, Blomberg A, et al. Acute exposure to diesel exhaust increases IL-8 and GROalpha Production in healthy human airways. $\mathrm{Am}$ J Respir Crit Care Med 2000; 161: 550-557.

14. Rudell B, Sandstrom T, Stjernberg N, KolmodinHedman B. Controlled diesel exhaust exposure in an exposure chamber: Pulmonary effects investigated with bronchoalveolar ravage. J Aerosol Sci 1990; 21: 411-414. 
15. Rudell B, Blomberg A, Helleday R, et al. Bronchoalveolar inflammation after exposure to diesel exhaust: comparison between unfiltered and particle trap filtered exhaust. Occup Environ Med 1999; 56: 527534.

16. Diaz Sanchez D, Tsien A, Fleming J, Saxon A. Combined diesel exhaust particulate and ragweed allergen challenge markedly enhances human in vivo nasal ragweed-specific IgE and skews cytokine production to a $\mathrm{T}$ helper cell 2-type pattern. $J$ Immunol 1997; 158: 2406-2413.

17. Rudell B, Sandstrom T, Hammarstrom U, Ledin ML, Horstedt P, Stjernberg N. Evaluation of an exposure setup for studying effects of diesel exhaust in humans. Int Arch Occup Environ Health 1994; 66: 77-83.

18. Juniper EF, Cockcroft DW, Hargreave FE. In: Histamine and Metacholine Inhalation Tests: Tidal breathing method. Laboratory Procedure and Standardization, 2nd edn. Lund, Sweden, Astra Draco AB, 1994.

19. Ryan G, Dolovich MB, Obminsky G. Standardization of provocation tests: Influence of nebulizer output, particle size and method of inhalation. J Allergy Clin Immunol 1981; 67: 156-161.

20. Pin I, Gibson PG, Kolendowicz R, et al. Use of induced sputum cell counts to investigate airway inflammation in asthma. Thorax 1992; 47: 25-29.

21. Pizzichini E, Pizzichini MM, Efthimiadis A, et al. Indices of airway inflammation in induced sputum: reproducibility and validity of cell and fluid-phase measurements. Am J Respir Crit Care Med 1996; 154: 308-317.

22. O'Byrne PM, Dolovich J, Hargreave FE. Late asthmatic responses. Am Rev Respir Dis 1987; 136: 740-751.

23. Steerenberg PA, Zonnenberg JA, Dormans JA, et al. Diesel exhaust particles induced release of interleukin-6 and -8 by (primed) human bronchial epithelial cells (BEAS 2B) in vitro. Exp Lung Res 1998; 24: 85-100.

24. Miyabara Y, Ichinose T, Takano H, Sagai M. Diesel exhaust inhalation enhances airway hyperresponsiveness in mice. Int Arch Allergy Immunol 1998; 116: 124-131.

25. Takano H, Ichinose T, Miyabara Y, Yoshikawa T, Sagai M. Diesel exhaust particles enhance airway responsiveness following allergen exposure in mice. Immunopharmacol Immunotoxicol 1998; 20: 329-336.

26. Takano H, Ichinose T, Miyabara Y, et al. Inhalation of diesel exhaust enhances allergen-related eosinophil recruitment and airway hyperresponsiveness in mice. Toxicol Appl Pharmacol 1998; 150: 328-337.

27. Takano H, Yoshikawa T, Ichinose T, Miyabara Y, Imaoka K, Sagai M. Diesel exhaust particles enhance antigen-induced airway inflammation and local cytokine expression in mice. Am J Respir Crit Care Med 1997; 156: 36-42.

28. Sagai M, Furuyama A, Ichinose T. Biological effects of diesel exhaust particles (DEP). III. Pathogenesis of asthma like symptoms in mice. Free Radic Biol Med 1996; 21: 199-209.

29. Strand V, Salomonsson P, Lundahl J, Bylin G. Immediate and delayed effects of nitrogen dioxide exposure at an ambient level on bronchial responsiveness to histamine in subjects with asthma. Eur Respir $J$ 1996; 9: 733-740.

30. Jorres R, Magnussen H. Effect of 0.25 ppm nitrogen dioxide on the airway response to methacholine in asymptomatic asthmatic patients. Lung 1991; 169: 77-85.

31. Roger LJ, Horstman DH, McDonnell W, et al. Pulmonary function, airway responsiveness, and respiratory symptoms in asthmatics following exercise in $\mathrm{NO}_{2}$. Toxicol Ind Health 1990; 6: 155-171.

32. Schwartz J. Air pollution and daily mortality: a review and meta-analysis. Environ Res 1994; 64: 36-52.

33. Pope CA 3rd, Schwartz J, Ransom MR. Daily mortality and PM10 pollution in Utah Valley. Arch Environ Health 1992; 47: 211-217.

34. UN Environment Program WHO report. Air pollution of the World's Megacities. A report from the UN Environment Program and WHO. Environment 1994; 36: 5-37. 